\title{
Long records of climate in southern Australasia
}

Timothy T. Barrows ${ }^{1}$ and Patrick De Deckker ${ }^{2}$

'Department of Nuclear Physics, Research School of Physical Sciences and Engineering, Australian National University, Canberra, Australia; Tim.Barrows@anu.edu.au; 2Department of Earth and Marine Sciences, Australian National University, Canberra, Australia

Australia, being an arid continent, suffers from a lack of long, well-dated records that can accurately document climate change. Most of our records are fragmentary, like lake shorelines or moraines, or can be difficult to decipher, like pollen records. Our approach has been to turn to the oceans that surround Australia and New Zealand to provide quality records of climate change through time. Marine records are more continuous, easier to date, and temperature change is easier to quantify. Additionally, wind and water transport evidence of changing climates from the continent into the ocean, to be preserved in these deep-sea sediments. The juxtaposition of continental and marine sediments provides a Rosetta Stone from which to interpret undated or ambiguous terrestrial records nearby.

In our most recent paper (Barrows et al., 2007), four cores (SO136-GC3, DSDP site 594, MD88-770, MD97-2120) were selected from around the mid-latitude southern margins of Australia and New Zealand (Fig. 1) to benchmark sea-surface temperature (SST) variations over the last 150 kyrs. Published records of terrestrial climate change are available for three of these cores. DSDP site 594 contains a pollen record (Heusser and Van de Geer, 1994) and a clastic record of glaciation from the South Island of New Zealand (Nelson et al., 1993). Both MD88-770 and MD97-2120 contain sediment records from a mixture of sources. To provide an absolute timescale, the oxygen isotope records from each core were matched with North Atlantic Ocean core MD95-2042 on the GISP2 ice core timescale (Shackleton et al., 2004). This permits us to make comparisons between the records and the timing of orbital variations without being constrained by an orbitally tuned chronology.

We gathered SST data for each core for the last glacial cycle. For our new core, S0136-GC3, we counted planktonic foraminifera and estimated SST using three independent approaches with a new core top database (Barrows and Juggins, 2005). We also used this approach to standardize the SST estimates using foraminifera data (Labeyrie et al., 1996; Weaver et al., 1998; Wells and Okada, 1997) from DSDP site 594 and MD88-770. For MD97-2120, existing $\mathrm{Mg} / \mathrm{Ca} \mathrm{SST}$ estimates (Pahnke et al., 2003) were used. Finally, we stacked the two best records from MD88-770 and

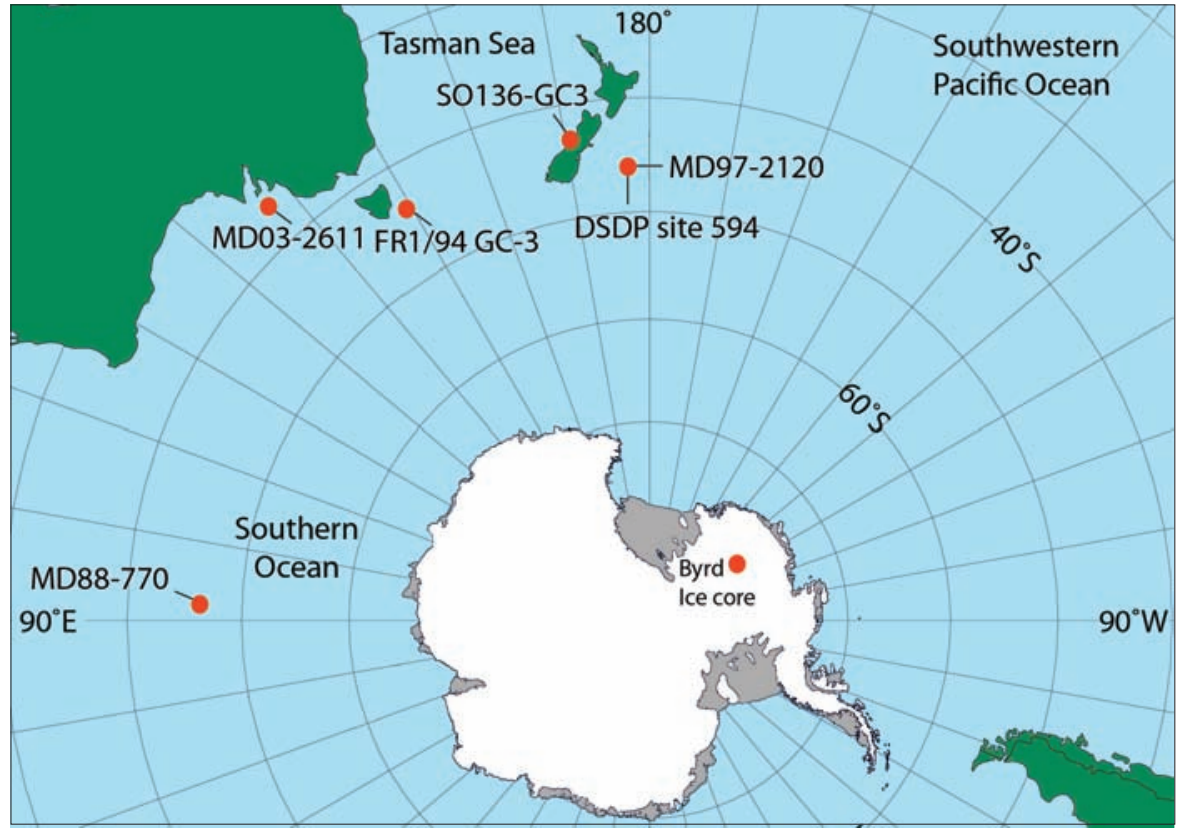

Figure 1: Map showing localities referred to in the text.

MD97-2120 to estimate average SST of the Southern Ocean (Fig. 2).

We found that there are obvious similarities between the SST records and the terrestrial records of climate change. Both glaciation on land and changes in vegetation occur in tandem with SST change, signifying a close link between the marine and terrestrial realms. When the timing of SST fluctuations in the SST stack is compared with the timing of changes in midsummer insolation at $65^{\circ} \mathrm{N}$, it was found that they agree within error without systematic leads or lags. This supports the idea that the beat of long-term climate change is driven from the northern hemisphere, and that insolation changes in the southern hemisphere are of secondary importance. The matches also occur for the terrestrial records in the cores. The SST records (the lower latitude ones in particular) bear a strong resemblance to ice core carbon dioxide records and have a high correlation with those records. It seems likely then that greenhouse gas changes are the prime candidate for synchronizing southern and northern hemisphere records.

The matches between the proxy climate records and orbital variations are poorest during glacial periods when variations on the suborbital timescale dominate. These variations cannot be explained by orbital theory and are most pronounced in the southern-most cores during periods of high ice volume (Fig. 2). The four most prominent warming peaks in Oxygen Isotope Chronozone 3 occur about 6-7 kyr apart, at almost the same time as the A1A4 events in the Antarctic Byrd ice core (Blunier and Brook, 2001). Similar features also occur in the terrestrial records, meaning they are widespread phenomena in the Australasian sector of the southern hemisphere. When compared to similar events in Greenland ice (Fig. 2), the warming before these southern hemisphere SST events, and the events themselves, occur shortly before their contemporaries in the northern hemisphere. This lead is what would be expected with a bipolar seesaw operating between the hemispheres (Broecker, 1998).

The other aspect of the millennial timescale climate change is the speed at which it occurs. Warming in the Southern Ocean core (MD88-770) by as much as $5-6^{\circ} \mathrm{C}$ occurs in less than 200 years. Cooling is only slightly slower than this. The record of glacier extent in DSDP site 594 mirrors these changes, indicating the rapid temperature change is also felt at the same time on land. Similarly, forest expansion according to the pollen record is very rapid at the start of interglacials as the ocean warms up quickly and glaciers retreat. The synchrony over the region indicates a common cause for climate change and close meteorological links between land and sea.

As part of an ongoing effort at the Australian National University, we are looking to other cores to further characterize longterm climate change in the Australasian region, and to better date and quantify terrestrial climate records. In particular, we 


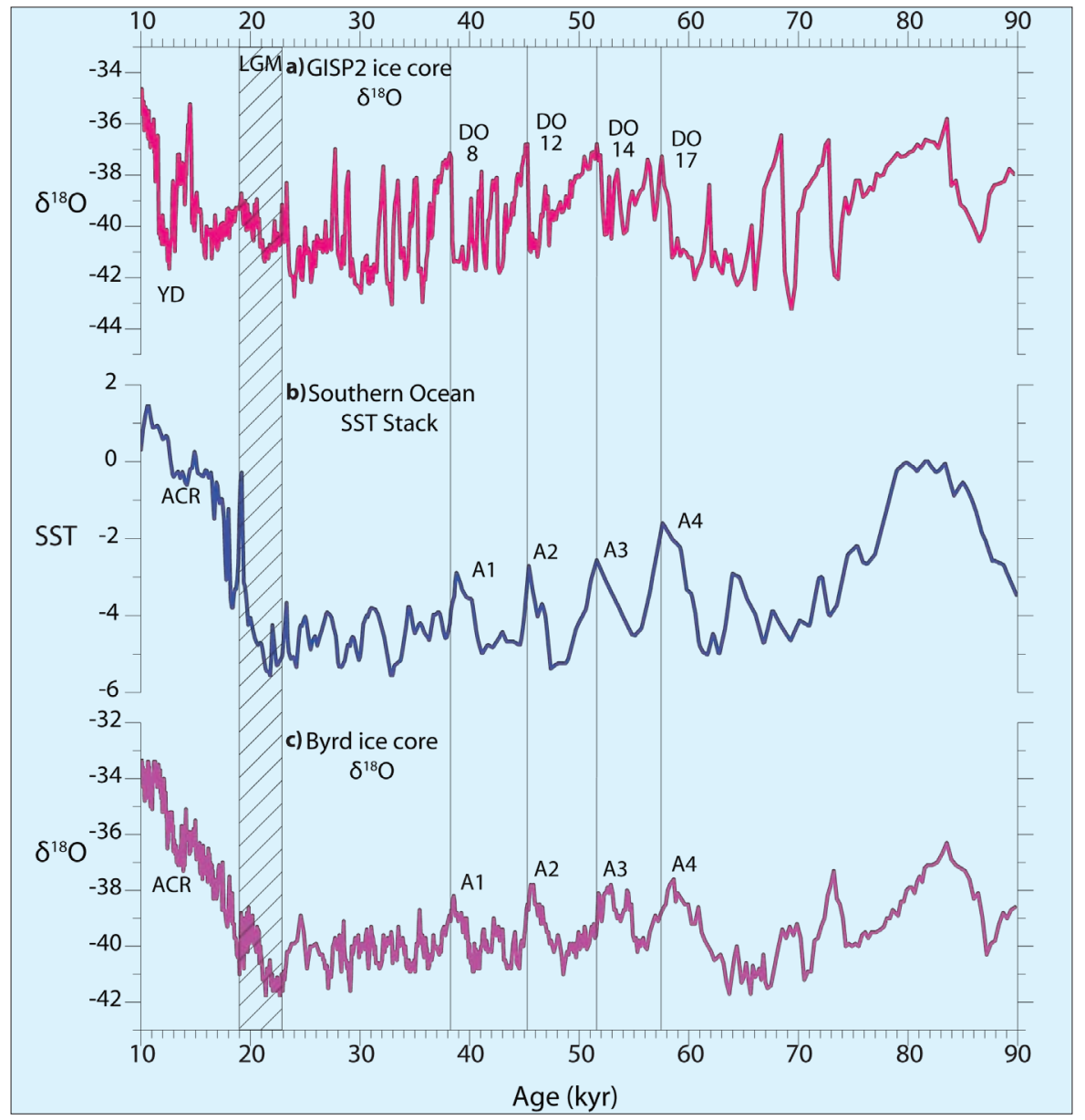

Figure 2: a) Comparison between the GISP 2 oxygen isotope record (Grootes et al., 1993) on the Meese et al. (1997) timescale; b) Southern Ocean SST stack; and c) Byrd ice core oxygen isotope record (Johnsen et al., 1972) on the Blunier and Brook (2001) GISP2 timescale. Note the similar shape shared by the two southern records compared to the northern one. $L G M=$ last glacial maximum (19-23 kyr), $A C R=$ Antarctic Cold Reversal, YD=Younger Dryas Chronozone cooling event. From Barrows et al. (2007).

are studying two cores with high sedimentation rates offshore of the mouth of the Murray River, which drains part of the vast Murray-Darling Basin $\left(\sim 1.10^{6} \mathrm{~km}^{2}\right)$. These cores (especially MD03-2611) promise to provide a link between difficult-to-date ing of glacial periods through time (Pelejero et al., 2006). Work is continuing on this core to develop a higher resolution SST record from planktonic foraminifera and to complete a pollen record that will allow us to study vegetation changes in Tasmania over the last half a million years.

Clearly, climate change is more complicated in the southern hemisphere than originally thought. Although we march to the beat of the same drum as the northern hemisphere, over timescales greater than $20 \mathrm{kyr}$, regional climate in the southern hemisphere has its own melody.

\section{Note}

A full list of references to the data referred to above can be found in Barrows et al. (2007). The above research contributes to the $\mathrm{PASH} 2$ project. Dates from this paper can be obtained from the World Data Center-A for Paleoclimatology.

\section{References}

Barrows, T.T. and Juggins, S., 2005: Sea-surface temperatures around the Australian margin and Indian Ocean during the Last Glacial Maximum, Quaternary Science Reviews, 24: 1017-1047.

Barrows, T.T., Juggins, S., De Deckker, P., Calvo, E. and Pelejero, C., 2007 : Long-term sea-surface temperature and climate change in the Australian-New Zealand region, Paleoceanography, 22: PA 2215 doi:10.1029/2006PA001328.

Gingele, F.X., De Deckker, P. and Hillenbrand, C.-D., 2004: Late Quaternary terrigenous sediments from the Murray Canyons area, offshore South Australia and their implications for sea level change, palaeoclimate and palaeodrainage of the Murray-Darling Basin, Marine Geology, 212: 183-197.

Gingele, F.X., De Deckker, P. and Norman, M., 2007: Late Pleistocene and Holocene climate of SE Australia reconstructed from dust and river loads deposited offshore the River Murray Mouth, Earth and Planetary Science Letters, 255: 257-272.

Pelejero, C., Calvo, E., Barrows, T.T., Logan, G.A. and De Deckker, P., 2006 South Tasman Sea alkenone palaeothermometry over the last four glacial/interglacial cycles, Marine Geology, 230(1-2): 73-86.

deposited offshore (Gingele et al., 2004, 2007). Preliminary results from FR1/94GC3 offshore from Tasmania-spanning the last $450 \mathrm{kyr}$ - provide an SST record that clearly points to a progressive warm-
For full references please consult:

www.pages-igbp.org/products/newsletter/ref2007_2.htm

\section{Dynamic Antarctic Ice: Agent for Mid-Pleistocene Transition}

\section{Jim M. Bowler And Mike SANDiford}

School of Earth Sciences, University of Melbourne, Australia; jbowler@unimelb.edu.au

In the record of Plio-Pleistocene climatic evolution, the Antarctic Ice Sheet is generally seen as a passive response to global change, rather than an active agent in its own right. While changes in global relief, particularly the uplift of the Qinghai-Tibet Plateau, are accepted as major drivers into cold, full-glacial $100 \mathrm{kyr}$ cycles (Ruddiman and Kutzbach, 1989; An et al., 2001), the potential influence of change in the Antarctic ice cap has largely escaped attention. The southern Australian coastline, facing the Antarctic continent with some $3000 \mathrm{~km}$ of unbroken fetch, is ideally placed to record changes in Southern Ocean dynamics. As the pattern of travel- ling cyclonic depressions that control the westerly flow across southern Australia reflects steep thermal gradients around the Antarctic margin, the winds and wave regimes impacting southern Australia can be linked to thermal conditions at the Antarctic margin. Changes in one of these systems imply correlative changes in the other. Here, we argue that evidence for dramatic mid-Pleistocene change in Southern Ocean dynamics is present in a remarkable succession of stranded shorelines in the Murray Basin in southeastern Australia, that provides a more-or-less complete record of paleoshorelines deposited over the last 6 Myr (Fig.1a).

\section{The Murray Basin record}

Situated in a relatively stable context, the Murray Basin has acted as an epeiric (epicontinental) sea controlled by the Southern Ocean for some 40 Myr. A mid-Miocene regression (12-7 Myr) was followed by an Upper Miocene transgression (6.5-6 Myr) with the maximum late Neogene marine incursion typically extending inland to heights $\sim 60 \mathrm{~m}$ above present day sea level (Brown and Stephenson, 1991). Regression from Upper Miocene through Pliocene to present time has left more than 170 shore parallel strandline ridges extending from $500 \mathrm{~km}$ inland from the present coast near Naracoorte (Fig. 1b,c). For some 200 km 